\title{
'Bing' Sweet Cherry Leaf Nutrition is Affected by Rootstock
}

\author{
Gerry Neilsen and Frank Kappel \\ Agriculture and Agri-Food Canada, Research Centre, Summerland, B.C. VOH \\ 1ZO, Canada
}

Additional index words. Prunus avium, leaf mineral concentration

\begin{abstract}
Leaf nutrient concentration of 'Bing' sweet cherry (Prunus avium L.) was affected by rootstock over 4 years in the Pacific Northwest. Trees on GM 79, GI 148/1, GI 195/1, and GI 196/4, which had higher yields than Mazzard, also had lower leaf $K$ and, excepting GM 79, lower leaf Mg concentration. Use of GI 195/1 and 196/4 resulted in lower leaf $\mathrm{N}$ than use of Mazzard. These higher-yielding rootstocks will require greater attention to these macronutrients, especially on infertile soil sites. Micronutrient nutrition was little affected by rootstocks, which tended to have the low leaf $\mathrm{Zn}$ concentrations typical of irrigated Pacific Northwest orchards. GM 9 and GM 61/1 rootstocks were more dwarfing than Mazzard, with GM 9 leaves having lower $\mathrm{K}$, but higher $\mathrm{P}, \mathrm{Mg}$, and $\mathrm{Mn}$ concentrations. GM 61/1 had lower leaf concentrations of most nutrients relative to Mazzard.
\end{abstract}

Rootstock affects leaf nutrient concentrations in a range of fruit crops (Brown and Cummins, 1989; Chaplin and Westwood, 1980; Fallahi and Westwood, 1984; Lord et al., 1985; Simons and Swiader, 1985). Research on the nutritional effects of cherry rootstocks has been limited mostly to sour cherry (Prunus cerasus L.) (Hanson and Perry, 1989; Jadczuk, 1993; Ugolik and Hulobowicz, 1990). To our knowledge, little information has been reported for sweet cherry scions, although Mazzard (F 12/1) rootstock resulted in higher leaf K than Prunus mahaleb L. and higher leaf $\mathrm{N}$ but lower leaf $\mathrm{Ca}$ and $\mathrm{Mg}$ than Colt (Hanson and Proebsting, 1995). Lower leaf N and K concentrations also were measured on three sweet cherry cultivars grown on Colt relative to $\mathrm{F} 12 / 1$ rootstock, whereas for $\mathrm{P}$, differences between the rootstocks varied with cultivar (Ystaas, 1990).

There is continuing commercial interest in cherry rootstocks, especially those likely to be more precocious or dwarfing than Mazzard, the current standard in North America (Perry, 1987). Cropping is known to affect nutrient uptake and leaf concentration of apple (Malus domestica Borkh.) (Hanson, 1980), but less is known about the nutritional consequences of heavy fruit cropping in cherry. Similarly, little is known concerning the nutritional consequences of potentially less vigorous rootstocks.

An investigation of the effects on leaf nutrition of several promising new cherry rootstocks was carried out over 4 years with 'Bing' sweet cherry in the Pacific Northwest.

Received for publication 16 Jan. 1996. Accepted for publication 8 July 1996. Summerland Research Centre contribution no. 957. We acknowledge the able technical assistance of B. Drought, A. Martin, and $\mathrm{M}$. Bouthillier.The cost of publishing this pape was defrayed in part by the payment of page charges. Under postal regulations, this paper therefore must be hereby marked advertisement solely to indicate this fact.

\section{Materials and Methods}

As part of the NC-140 cooperative trials on cherry rootstocks, coordinated by R.L. Perry of Michigan State Univ., two experimental plantings were established at the Summerland Research Centre located in southern interior British Columbia. At site 1, 'Bing' sweet cherry on seven rootstocks, spaced at $6.1 \times 6.1 \mathrm{~m}$, were planted in 1987 in a randomized complete-block design with eight single-tree replications. Rootstocks at this site include Colt $(P$. avium $\mathrm{x} P$. pseudocerasus Lindley), GM 79 ( $P$. canescens Buis), GM 61/1 ( $P$. $\times$ dawyckensis Sealy), GM 9 (P. incisa Thunb $x P$. serrulata Lindley), MxM46 ( $P$. mahaleb $\mathrm{X} P$. avium), MxM2 and Mazzard, the latter considered the standard or control treatment. The Mazzard rootstock was propagated by Hilltop Nurseries (Washington State) and was Michigan-certified virus-free. Site 2 was planted in 1988 at the same spacing in a randomized complete-block design with eight single-tree replications of five rootstocks with 'Bing' sweet cherry on GI 148/1 (P. cerasus X $P$. canescens), GI 195/1 (P. canescens $\times P$. cerasus), GI 196/4 (P. canescens $\times$ P. avium), MxM60 in addition to the standard Mazzard.

The sites were within $200 \mathrm{~m}$ of each other on a Skaha gravelly sandy loam (Wittneben, 1986), a common fruit-growing soil series located throughout the southern part of the Okanagan Valley. No detailed soil sampling was undertaken at the experimental sites. However, these Orthic Brown soils generally drain rapidly, have low water-holding capacity, low organic matter, low $\mathrm{N}$ and $\mathrm{P}$ content, neutral soil $\mathrm{pH}$, and overlay coarse-textured subsoils ranging from gravelly loamy sands to loamy sands. Typical surface soil samples from this soil series contained $1 \mathrm{M} \mathrm{NH}_{4} \mathrm{OAC}$-exchangeable $\mathrm{Ca}, \mathrm{Mg}$, and $\mathrm{K}$ concentrations averaging 1047,148 , and $126 \mu \mathrm{g} \cdot \mathrm{g}^{-1}$, respectively (Neilsen and Hogue, 1992). Standard commercial production practices were used to control insects and disease and irrigation was applied via under-tree sprinklers generally from May to
October, as required (British Columbia Ministry of Agriculture, Fisheries and Food, 1995). Nitrogen fertilizer was routinely broadcast on a field basis. At site $1, \mathrm{~N}$ at $76 \mathrm{~kg} \cdot \mathrm{ha}^{-1}$ was applied in Oct./Nov. 1989 and 1990 and $\mathrm{N}$ at $57 \mathrm{~kg} \cdot \mathrm{ha}^{-1}$ in Oct./Nov. 1991 and 1992 and Spring 1993, all as ammonium nitrate $(34 \mathrm{~N}$ $\mathrm{OP}-0 \mathrm{~K})$. For site 2, ammonium nitrate applications of $\mathrm{N}$ at $76 \mathrm{~kg} \cdot \mathrm{ha}^{-1}$ also were made in Oct./Nov. 1989-90, but urea (46N-0P-0K) was applied at $103 \mathrm{~kg} \cdot \mathrm{ha}^{-1} \mathrm{~N}$ in Oct./Nov. 1991-92 and Spring 1993 to accommodate other plantings in the same field. Both sites also received Production Guide (British Columbia Ministry of Agriculture, Fisheries and Food, 1995) recommended $\mathrm{Zn}$ applications in the late dormant period (March-April) each year at $40 \mathrm{~kg} \cdot \mathrm{ha}^{-1}$ zinc sulfate $(36 \% \mathrm{Zn})$.

Annual measurements were made of yield at commercial harvest and trunk diameter at 0.3-m height from which trunk cross-sectional area (TCA) was calculated. Leaf samples were collected for each of the 4 years from 1990 to 1993 from all replications and rootstocks at each site. For site 1, leaf samples thus were collected from the fourth to seventh and for site 2 from the third to sixth year after orchard establishment. For both sites, these represented the first fruiting years. Samples comprised 30 leaves collected from the midthird portion of extension shoots of the current-years' growth at the standard midsummer sampling period (mid-July to early August). All samples were oven-dried at $65^{\circ} \mathrm{C}$ and ground in a stainless steel mill. A 250-mg subsample was digested for $0.75 \mathrm{~h}$ on a block digester at $350^{\circ} \mathrm{C}$ in a $\mathrm{H}_{2} \mathrm{SO}_{4}$ solution containing $\mathrm{K}_{2} \mathrm{SO}_{4}$ and $\mathrm{HgO}$. Nitrogen in the digest was determined after formation of a phosphomolybdenum complex (Technicon Autoanalyzer II Industrial Method No. 334-74 A/A; Technicon, Elmsford, N.Y). One-gram samples were dry-ashed at $475^{\circ} \mathrm{C}$ and dissolved in $0.5 \mathrm{M} \mathrm{HCl}$ before determination of $\mathrm{Ca}, \mathrm{Mg}, \mathrm{K}, \mathrm{Mn}, \mathrm{Zn}, \mathrm{Fe}$, and $\mathrm{Cu}$ by atomic absorption spectrophotometry.

For each orchard site, leaf nutrient data were analyzed by repeated measures analysis of variance (ANOVA) (SAS Inst., 1985). Generally, there was a significant time $\times$ rootstock interaction with the exception of leaf $\mathrm{Fe}$ (both sites), leaf $\mathrm{Ca}$ (site 1), and leaf $\mathrm{Zn}$ (site 2). Subsequent data presentation thus focuses on leaf nutrient means for each rootstock and year. Cumulative yield during the leaf sampling period, 1990-93, TCA in 1993, and cumulative yield efficiency 1990-93 (cumulative 1990-93 yield divided by TCA 1993) were subjected to a separate ANOVA with eight replications for each site.

\section{Results and Discussion}

Yield and vigor. During the period of leaf sampling from 1990 to 1993, 'Bing' fruit yield was significantly affected by rootstock at both study sites, while average TCA at the end of the project in 1993 was significantly affected at site 1 (Table 1). At site 1, cumulative yield was significantly higher for 'Bing' grown on GM 79 rootstock than on Mazzard. Cumulative yield efficiency was higher for trees on 
GM 79 and GM 61/1 rootstocks. By 1993, trees on Colt were larger and trees on GM 61/ 1 or GM9 were smaller than those on Mazzard. The limited dwarfing capability of Colt in North America was previously noted (Perry, 1987). At site 2, rootstocks GI 148/1, GI 195/ 1, and GI 196/4 had higher cumulative yield and yield efficiency than Mazzard rootstock despite lack of differences in tree size (TCA) among rootstocks. For some deciduous fruit crops, especially apple, crop load can have a major influence on leaf nutrient concentration (Bould, 1966). Little work has been reported on this effect for sweet cherry, although Jadczuk (1993) reported decreased leaf K with increased crop load for sour cherry. Hanson (1980) suggested leaf N, P, and K concentration of apple decrease as crop load increases. It would, therefore, be expected that some differences in leaf nutrient concentration between various rootstocks and Mazzard could reflect differences in cropping. For example, if cherry were to behave similarly to apple, lower leaf $\mathrm{K}$ relative to Mazzard might be expected for 'Bing' cherry on higher-yielding GM 79, GI 148/1, GI 195/1, and GI 196/4 rootstocks.

Leaf $N$ and $P$. Leaf $\mathrm{N}$ concentration was significantly increased or decreased relative to Mazzard on 35\% (14 of 40) of the rootstockyear occasions at the two sites (Table 2). Usually, leaf $\mathrm{N}$ concentration was lower than for Mazzard (nine occasions) with leaf $\mathrm{N}$ on rootstocks GM 61/1 and GI 195/1 lower in 3 years and lower in 2 years on GI 196/4. These rootstocks had higher yields or cumulative yield efficiency (GM 61/1) than Mazzard, which is consistent with decreased leaf $\mathrm{N}$ concentrations when crop load increases for apple and implies a need to increase $\mathrm{N}$ fertilization rates of precocious rootstocks. In contrast, the low-yielding MxM60 rootstock and low-vigor GM9 had higher leaf $\mathrm{N}$ concentrations than Mazzard in 2 years. Leaf $\mathrm{N}$ concentrations were generally above $1.9 \%$, which is considered adequate for growth (British Columbia Ministry of Agriculture, Fisheries and Food, 1995), with the exception of GM 61/1 in 3 years and all, except rootstock GM9, in 1993 at site 1 (Table 3). As indicated by the leaf $\mathrm{N}$ concentration of 'Bing' on Mazzard, leaf $\mathrm{N}$ concentrations were generally lower at site 1 , which received lower rates of $\mathrm{N}$ fertilizer during the study. The very low leaf $\mathrm{N}$ concentration for trees on GM 61/1 implies that these trees might have higher yield at higher rates of $\mathrm{N}$ fertilization.

Leaf $\mathrm{P}$ concentration was less frequently affected by rootstock than leaf $\mathrm{N}$, with the most noteworthy effects being a tendency to higher leaf P on GM 9 (3 years) and Colt rootstocks (2 years) relative to Mazzard (Table 2). The higher leaf $P$ concentration for 'Bing' on GM 9 may reflect lack of dilution of $\mathrm{P}$ due to the smaller size of these trees. Leaf P concentrations were, however, consistently adequate for all rootstocks in all years, with minimum leaf $\mathrm{P}$ concentration for any rootstock-year combination averaging $0.29 \%$ and $0.19 \%$, respectively, at sites 1 and 2 (detailed data not shown).

Table 1. Average cumulative yield and yield efficiency, 1990-93, and average trunk cross-sectional area (TCA) in 1993 for 'Bing' sweet cherry grown on various rootstocks in two experimental plantings.

\begin{tabular}{|c|c|c|c|}
\hline Rootstock & $\begin{array}{c}\text { Cumulative yield } \\
(1990-93) \\
(\mathrm{kg} / \text { tree })\end{array}$ & $\begin{array}{c}\text { Cumulative yield } \\
\text { efficiency }(1990-93) \\
\left(\mathrm{kg} \cdot \mathrm{cm}^{-2}\right)\end{array}$ & $\begin{array}{l}\text { TCA } \\
\left(\mathrm{cm}^{2}\right)\end{array}$ \\
\hline \multicolumn{4}{|c|}{ Site 1} \\
\hline Colt & $19.4 a b^{z}$ & $0.083 \mathrm{c}$ & $227 \mathrm{a}$ \\
\hline GM 79 & $29.8 \mathrm{a}$ & $0.274 \mathrm{a}$ & $103 \mathrm{~cd}$ \\
\hline GM 61/1 & $18.2 \mathrm{~b}$ & $0.248 \mathrm{ab}$ & $78 \mathrm{~d}$ \\
\hline GM 9 & $6.6 \mathrm{c}$ & $0.083 \mathrm{c}$ & $74 \mathrm{~d}$ \\
\hline MxM46 & $23.3 \mathrm{ab}$ & $0.156 b c$ & $148 \mathrm{bc}$ \\
\hline MxM2 & $14.7 \mathrm{bc}$ & $0.085 \mathrm{c}$ & $167 \mathrm{~b}$ \\
\hline Mazzard & $14.4 \mathrm{bc}$ & $0.129 \mathrm{c}$ & $144 \mathrm{bc}$ \\
\hline Statistical & & & \\
\hline significance & $* *$ & $* * *$ & $* * * *$ \\
\hline \multicolumn{4}{|c|}{ Site 2} \\
\hline GI $148 / 1$ & $47.5 \mathrm{a}$ & $0.324 \mathrm{a}$ & 155 \\
\hline GI $195 / 1$ & $47.7 \mathrm{a}$ & $0.306 \mathrm{a}$ & 158 \\
\hline GI $196 / 4$ & $53.7 \mathrm{a}$ & $0.296 \mathrm{a}$ & 182 \\
\hline MxM60 & $12.9 \mathrm{~b}$ & $0.069 \mathrm{~b}$ & 210 \\
\hline Mazzard & $7.1 \mathrm{~b}$ & $0.041 \mathrm{~b}$ & 161 \\
\hline Significance & $* * * *$ & $* * * *$ & NS \\
\hline
\end{tabular}

${ }^{\overline{ }}$ Mean separation in columns by Duncan's multiple range test at $P \leq 0.05$.

Ns, ${ }^{* *}, * * *, * * * *$ Nonsignificant or significant at $P \leq 0.01,0.001$, or 0.0001 , respectively.

Table 2. Number of years leaf nutrient concentration of 'Bing' sweet cherry significantly $(P \leq 0.05)$ increased (+) or decreased (-) for indicated rootstock relative to Mazzard, 1990-93.

\begin{tabular}{|c|c|c|c|c|c|c|c|c|c|}
\hline \multirow[b]{2}{*}{ Rootstock } & \multicolumn{9}{|c|}{ Nutrient } \\
\hline & $\mathrm{N}$ & $\mathrm{P}$ & $\mathrm{K}$ & $\mathrm{Ca}$ & $\mathrm{Mg}$ & $\mathrm{Zn}$ & $\mathrm{Fe}$ & $\mathrm{Mn}$ & $\mathrm{Cu}$ \\
\hline \multicolumn{10}{|l|}{ Site 1} \\
\hline Colt & 0 & $2(+)$ & $4(-)$ & $4(+)$ & $4(+)$ & 0 & 0 & 0 & 0 \\
\hline GM 79 & $1(-)$ & 0 & $4(-)$ & $2(+)$ & $4(+)$ & $1(+)$ & 0 & 0 & 0 \\
\hline GM 61/1 & $3(-)$ & $1(-)$ & $4(-)$ & $2(-)$ & 0 & $1(-)$ & $2(-)$ & $2(-)$ & $3(-)$ \\
\hline GM 9 & $2(+)$ & $3(+)$ & $2(-)$ & 0 & $3(+)$ & $2(+)$ & 0 & $3(+)$ & 0 \\
\hline MxM46 & 0 & 0 & $1(-)$ & $2(-)$ & 0 & 0 & 0 & $1(-)$ & 0 \\
\hline MxM2 & 0 & 0 & $1(+)$ & 0 & 0 & 0 & 0 & $2(-)$ & $3(+)$ \\
\hline \multicolumn{10}{|l|}{ Site 2} \\
\hline GI 148/1 & 0 & 0 & $3(-)$ & 0 & $2(-)$ & 0 & 0 & 0 & $1(-)$ \\
\hline GI $195 / 1$ & $3(-)$ & $1(-)$ & $3(-)$ & 0 & $2(-)$ & 0 & $1(-)$ & 0 & $3(-)$ \\
\hline GI 196/4 & $1(+), 2(-)$ & 0 & $3(-)$ & $2(+)$ & $2(-)$ & 0 & 0 & $2(+)$ & $1(+), 1(-)$ \\
\hline MxM60 & $2(+)$ & 0 & 0 & $3(-)$ & $4(-)$ & 0 & 0 & $1(-)$ & 0 \\
\hline \multicolumn{10}{|c|}{ Cumulative rootstock-year effects } \\
\hline & $5(+)$ & $5(+)$ & $1(+)$ & $8(+)$ & $11(+)$ & $3(+)$ & & $5(+)$ & $4(+)$ \\
\hline & $9(-)$ & $2(-)$ & $24(-)$ & $7(-)$ & $10(-)$ & $1(-)$ & $3(-)$ & $6(-)$ & $8(-)$ \\
\hline
\end{tabular}

Leaf $\mathrm{K}, \mathrm{Mg}$, and $\mathrm{Ca}$. The leaf concentrations of $\mathrm{K}, \mathrm{Mg}$, and $\mathrm{Ca}$ were most affected by rootstock of all the nutrients measured when comparisons were made with Mazzard (Table 2).

Leaf $\mathrm{K}$ was always ( 4 of 4 years) lower than in Mazzard for trees on Colt, GM 79 and GM $61 / 1$, whereas leaf $\mathrm{K}$ was usually ( 3 of 4 years) lower for GI 148/1, GI 195/1, and GI 196/4 and was lower in 2 of 4 years on GM 9. Decreased leaf $\mathrm{K}$ is associated with heavier cropping (Table 1) in some of the rootstocks (GM 79, GI 148/1, GI 195/1, and GI 196/4). Low leaf K for Colt, GM 61/1, and GM 9 would, however, imply less efficient uptake of $\mathrm{K}$ by these rootstocks due to their similar yield relative to Mazzard. Leaf K, however, was not highest for rootstocks during 1990 when yields were lowest $(<1 \mathrm{~kg} /$ tree $)$, implying factors other than crop load were affecting leaf K. For most of the rootstocks, leaf $\mathrm{K}$ values (Table 3) were still well above the deficiency concentration of 1\% (Shear and Faust, 1980). The lowest K concentrations and consistently low values were in trees on GM 61/1 rootstock, implying that this rootstock could be susceptible to $\mathrm{K}$ deficiency, especially on sites with lower soil supplies of K. Furthermore, given a possible association between heavier cropping and decreased leaf $K$ and the fact that these trees have yet to achieve maximum production, $\mathrm{K}$ nutrition will be more of a concern should rootstocks higher yielding than Mazzard be adopted by the industry.

Leaf $\mathrm{Mg}$ concentrations were frequently affected by rootstock. Leaf $\mathrm{Mg}$ concentrations for Colt, GM79, and GM9 rootstocks at site 1 were generally higher than for Mazzard, while all site 2 rootstocks, especially MxM60, accumulated lower leaf Mg concentrations (Table 2). Previously, Colt was much less susceptible to $\mathrm{Mg}$ deficiency than Mazzard (Webster and Schmidt, 1995). Our data confirm this tendency but also suggest that GM 79 and GM 9 rootstocks are less likely to develop Mg deficiency than Mazzard. The lowest leaf $\mathrm{Mg}$ concentrations were on MxM60 rootstock in 1993 (Table 3) but, at $0.26 \%$, were above values normally associated with $\mathrm{Mg}$ deficiency (Hanson and Proebsting, 1995). Nevertheless, MxM60 and the higher-yielding rootstocks GI 148/1, GI 195/1, and GI 196/4 may require greater attention to $\mathrm{Mg}$ nutrition than Mazzard.

As with $\mathrm{Mg}$, leaf $\mathrm{Ca}$ concentration was 
Table 3. Average leaf N, K, and Mg concentration (dry mass basis) of 'Bing' sweet cherry on various rootstocks in two experimental plantings, 1990-93.

\begin{tabular}{|c|c|c|c|c|c|c|c|c|c|c|c|c|}
\hline \multirow[b]{2}{*}{ Rootstock } & \multicolumn{4}{|c|}{$\mathrm{N}(\%)$} & \multicolumn{4}{|c|}{$\mathrm{K}(\%)$} & \multicolumn{4}{|c|}{$\operatorname{Mg}(\%)$} \\
\hline & 1990 & 1991 & 1992 & 1993 & 1990 & 1991 & 1992 & 1993 & 1990 & 1991 & 1992 & 1993 \\
\hline \multicolumn{13}{|l|}{ Site 1} \\
\hline Colt & $2.01 \mathrm{c}^{\mathrm{z}}$ & $2.05 \mathrm{~b}$ & $2.27 \mathrm{~cd}$ & 1.63 & $2.05 \mathrm{~b}$ & $1.84 \mathrm{~cd}$ & $2.54 \mathrm{c}$ & $1.80 \mathrm{bc}$ & $0.48 \mathrm{a}$ & $0.41 \mathrm{a}$ & $0.66 \mathrm{a}$ & $0.40 \mathrm{a}$ \\
\hline GM 79 & $2.13 \mathrm{bc}$ & $1.99 \mathrm{bc}$ & $2.16 \mathrm{~d}$ & 1.59 & $2.17 \mathrm{~b}$ & $1.91 \mathrm{bc}$ & $2.35 \mathrm{c}$ & $1.54 \mathrm{de}$ & $0.42 \mathrm{~b}$ & $0.38 \mathrm{a}$ & $0.55 \mathrm{~b}$ & $0.38 \mathrm{a}$ \\
\hline GM 61/1 & $1.81 \mathrm{~d}$ & $1.74 \mathrm{c}$ & $1.95 \mathrm{e}$ & 1.65 & $1.74 \mathrm{c}$ & $1.70 \mathrm{~d}$ & $1.82 \mathrm{~d}$ & $1.46 \mathrm{e}$ & $0.37 \mathrm{c}$ & $0.32 \mathrm{~b}$ & $0.44 \mathrm{~cd}$ & $0.32 \mathrm{~b}$ \\
\hline GM 9 & $2.40 \mathrm{a}$ & $2.45 \mathrm{a}$ & $2.98 \mathrm{a}$ & 1.92 & $2.08 \mathrm{~b}$ & $2.00 \mathrm{~b}$ & $2.82 \mathrm{~b}$ & $1.98 \mathrm{ab}$ & $0.45 \mathrm{ab}$ & $0.37 \mathrm{a}$ & $0.47 \mathrm{c}$ & $0.37 \mathrm{a}$ \\
\hline MxM46 & $2.11 b c$ & $1.97 \mathrm{bc}$ & $2.43 \mathrm{bc}$ & 1.70 & $2.51 \mathrm{a}$ & $2.22 \mathrm{a}$ & $3.00 \mathrm{ab}$ & $1.70 \mathrm{~cd}$ & $0.32 \mathrm{~d}$ & $0.28 \mathrm{~b}$ & $0.42 \mathrm{~cd}$ & $0.28 \mathrm{bc}$ \\
\hline MxM2 & $2.27 \mathrm{ab}$ & $2.25 \mathrm{ab}$ & $2.55 \mathrm{~b}$ & 1.85 & $2.55 \mathrm{a}$ & $2.33 \mathrm{a}$ & $3.14 \mathrm{a}$ & $2.04 \mathrm{a}$ & $0.31 \mathrm{~d}$ & $0.27 \mathrm{~b}$ & $0.38 \mathrm{~d}$ & $0.27 \mathrm{c}$ \\
\hline Mazzard & $2.10 \mathrm{bc}$ & $2.19 \mathrm{ab}$ & $2.43 \mathrm{bc}$ & 1.81 & $2.47 \mathrm{a}$ & $2.25 \mathrm{a}$ & $2.84 \mathrm{~b}$ & $2.16 \mathrm{a}$ & $0.31 \mathrm{~cd}$ & $0.32 \mathrm{~b}$ & $0.45 \mathrm{~cd}$ & $0.30 \mathrm{bc}$ \\
\hline $\begin{array}{l}\text { Statistical } \\
\quad \text { significance }\end{array}$ & $* * * *$ & $* * * *$ & $* * * *$ & NS & $* * * *$ & $* * * *$ & $* * * *$ & $* * * *$ & $* * * *$ & $* * * *$ & $* * * *$ & $* * * *$ \\
\hline \multicolumn{13}{|l|}{ Site 2} \\
\hline GI 148/1 & $2.78 \mathrm{~b}$ & $3.10 \mathrm{a}-\mathrm{c}$ & $2.65 \mathrm{bc}$ & $2.26 \mathrm{a}-\mathrm{c}$ & $1.77 \mathrm{~b}$ & $1.96 \mathrm{~b}$ & $1.78 \mathrm{~b}$ & $1.73 \mathrm{~b}$ & $0.34 \mathrm{bc}$ & $0.30 \mathrm{~b}$ & $0.48 \mathrm{a}$ & $0.30 \mathrm{a}$ \\
\hline GI $195 / 1$ & $2.53 \mathrm{c}$ & $3.00 \mathrm{bc}$ & $2.38 \mathrm{~d}$ & $2.05 \mathrm{c}$ & $1.76 \mathrm{~b}$ & $1.92 \mathrm{~b}$ & $1.58 \mathrm{~b}$ & $1.61 \mathrm{~b}$ & $0.37 \mathrm{~b}$ & $0.32 \mathrm{~b}$ & $0.49 \mathrm{a}$ & $0.32 \mathrm{a}$ \\
\hline GI 196/4 & $2.72 b c$ & $3.19 \mathrm{a}$ & $2.48 \mathrm{~cd}$ & $2.19 \mathrm{bc}$ & $1.85 \mathrm{~b}$ & $1.91 \mathrm{~b}$ & $1.73 \mathrm{~b}$ & $1.78 \mathrm{~b}$ & $0.38 \mathrm{~b}$ & $0.31 \mathrm{~b}$ & $0.50 \mathrm{a}$ & $0.33 \mathrm{a}$ \\
\hline MxM60 & $3.04 \mathrm{a}$ & $3.12 \mathrm{ab}$ & $2.97 \mathrm{a}$ & $2.38 \mathrm{ab}$ & $2.23 \mathrm{a}$ & $2.34 \mathrm{a}$ & $2.35 \mathrm{a}$ & $2.23 \mathrm{a}$ & $0.31 \mathrm{c}$ & $0.30 \mathrm{~b}$ & $0.37 \mathrm{~b}$ & $0.26 \mathrm{~b}$ \\
\hline Mazzard & $2.80 \mathrm{~b}$ & $2.94 \mathrm{c}$ & $2.86 \mathrm{ab}$ & $2.50 \mathrm{a}$ & $1.99 \mathrm{ab}$ & $2.21 \mathrm{a}$ & $2.17 \mathrm{a}$ & $2.23 \mathrm{a}$ & $0.42 \mathrm{a}$ & $0.38 \mathrm{a}$ & $0.48 \mathrm{a}$ & $0.32 \mathrm{a}$ \\
\hline Significance & $* *$ & $*$ & $* * * *$ & $*$ & $* *$ & $* * *$ & $* * * *$ & $* * * *$ & $* * *$ & $* *$ & $* * *$ & $* *$ \\
\hline
\end{tabular}

${ }^{2}$ Mean separation in columns by Duncan's multiple range test at $P \leq 0.05$.

ns, *,**,**,**** Nonsignificant or significant at $P \leq 0.05,0.01,0.001$, or 0.0001 , respectively.

affected by rootstock relative to Mazzard(Table 2). Colt consistently had a higher leaf $\mathrm{Ca}$ concentration than Mazzard, whereas GM 79 and GI 196/4 had significantly higher concentrations in 2 of the 4 years. In contrast, lower leaf Ca concentrations were measured for trees on MxM60 rootstock (3 years) and GM 61/1 and MxM46 (2 years). Leaf Ca concentrations were in the normal range, averaging near and above $1 \%$ for all rootstocks in all years (detailed data not shown), thus these differences were not expected to be of practical significance.

Micronutrient nutrition. In general, leaf $\mathrm{Zn}, \mathrm{Fe}, \mathrm{Mn}$, and $\mathrm{Cu}$ concentrations were less affected by rootstock than the major nutrients, and there were no consistent differences between the higher yielding rootstocks (GM 79, GI 148/1, GI 195/1, and GI 196/4) and Mazzard (Table 2).

Leaf $\mathrm{Zn}$ and $\mathrm{Fe}$ concentrations, of all the nutrients measured, were the least affected, relative to Mazzard. No rootstock, with the possible exception of GM9 for $\mathrm{Zn}$ (higher 2 years) and GM 61/1 for Fe (lower 2 years) had higher or lower leaf concentrations relative to Mazzard (Table 2). Leaf $\mathrm{Zn}$ concentrations were consistently low and considered inadequate for all rootstocks in all years (Table 4) despite the routine application of dormant $\mathrm{Zn}$ to these plantings. Similar patterns of $\mathrm{Zn}$ concentrations near or below commonly accepted deficiency concentrations have been observed in apple orchards in the Pacific Northwest despite routine $\mathrm{Zn}$ applications during dormancy (Neilsen, 1988). None of the tested cherry rootstocks offers a solution to the chronic low leaf $\mathrm{Zn}$ problems common in the Pacific Northwest. Although Fe chlorosis can occur on cherry, there is little relationship between the disorder and leaf Fe concentration (Shear and Faust, 1980). Consequently, little can be concluded regarding the relevance of the relatively lower leaf Fe on rootstock GM 61/1 (data not shown).

Rootstocks were identified that had higher or lower leaf $\mathrm{Mn}$ and $\mathrm{Cu}$ concentrations than Mazzard (Table 2); leaf Mn concentrations were higher for GM9 and GI 196/4 and lower

Table 4. Average leaf $\mathrm{Zn}$ and Mn concentration (dry mass basis) of 'Bing' sweet cherry on various rootstocks in two experimental plantings, 1990-93.

\begin{tabular}{|c|c|c|c|c|c|c|c|c|}
\hline \multirow[b]{2}{*}{ Rootstock } & \multicolumn{4}{|c|}{ Leaf $\mathrm{Zn}\left(\mu \mathrm{g} \cdot \mathrm{g}^{-1}\right)$} & \multicolumn{4}{|c|}{ Leaf Mn $\left(\mu \mathrm{g} \cdot \mathrm{g}^{-1}\right)$} \\
\hline & 1990 & 1991 & 1992 & 1993 & 1990 & 1991 & 1992 & 1993 \\
\hline \multicolumn{9}{|l|}{ Site 1} \\
\hline Colt & $8.7 a^{2}$ & $10.0 \mathrm{ab}$ & $10.9 \mathrm{~b}$ & $10.7 \mathrm{ab}$ & $44.2 \mathrm{bc}$ & $30.4 b c$ & $53.2 \mathrm{~b}$ & $37.0 \mathrm{a}-\mathrm{c}$ \\
\hline GM 79 & $9.7 \mathrm{a}$ & $7.7 \mathrm{bc}$ & $9.0 \mathrm{~b}$ & $11.2 \mathrm{a}$ & $51.9 \mathrm{ab}$ & $32.8 \mathrm{~b}$ & $53.2 \mathrm{~b}$ & $41.3 \mathrm{a}$ \\
\hline GM 61/1 & $7.4 \mathrm{c}$ & $7.5 \mathrm{c}$ & $8.6 \mathrm{~b}$ & $9.0 \mathrm{bc}$ & $31.1 \mathrm{c}$ & $19.4 \mathrm{c}$ & $33.4 \mathrm{~d}$ & $32.0 \mathrm{bc}$ \\
\hline GM 9 & $8.3 \mathrm{bc}$ & $11.2 \mathrm{a}$ & $14.3 \mathrm{a}$ & $11.9 \mathrm{a}$ & $63.3 \mathrm{a}$ & $45.3 \mathrm{a}$ & $67.9 \mathrm{a}$ & $41.8 \mathrm{a}$ \\
\hline MxM 46 & $7.8 \mathrm{bc}$ & $8.3 \mathrm{bc}$ & $11.2 \mathrm{~b}$ & $8.6 \mathrm{c}$ & $30.7 \mathrm{c}$ & $25.6 \mathrm{bc}$ & $41.5 \mathrm{~cd}$ & $28.7 \mathrm{c}$ \\
\hline MxM 2 & $8.4 \mathrm{bc}$ & $8.3 \mathrm{bc}$ & $9.7 \mathrm{~b}$ & $9.1 \mathrm{bc}$ & $32.0 \mathrm{c}$ & $23.7 \mathrm{bc}$ & $35.4 \mathrm{~d}$ & $29.3 \mathrm{c}$ \\
\hline Mazzard & $9.0 \mathrm{ab}$ & $9.8 \mathrm{a}-\mathrm{c}$ & $9.5 \mathrm{~b}$ & $9.3 \mathrm{bc}$ & $44.9 \mathrm{bc}$ & $32.8 \mathrm{~b}$ & $44.9 \mathrm{bc}$ & $38.9 \mathrm{ab}$ \\
\hline $\begin{array}{l}\text { Statistical } \\
\text { significance }\end{array}$ & $* *$ & $* *$ & $* * *$ & $* * *$ & $* * * *$ & ** & $* * * *$ & $* *$ \\
\hline \multicolumn{9}{|l|}{ Site 2} \\
\hline GI 148/1 & 11.2 & 12.3 & 10.1 & 14.0 & $55.4 \mathrm{~b}$ & $59.2 \mathrm{bc}$ & $75.1 \mathrm{ab}$ & $44.5 \mathrm{ab}$ \\
\hline GI 195/1 & 9.3 & 11.8 & 8.8 & 12.1 & $64.3 \mathrm{~b}$ & $66.6 \mathrm{~b}$ & 80.9 a & $47.6 \mathrm{a}$ \\
\hline GI 196/4 & 10.8 & 11.8 & 10.2 & 12.8 & $85.5 \mathrm{a}$ & $91.9 \mathrm{a}$ & $92.4 \mathrm{a}$ & $52.2 \mathrm{a}$ \\
\hline MxM 60 & 11.3 & 11.3 & 10.6 & 13.0 & $46.0 \mathrm{~b}$ & $45.7 \mathrm{c}$ & $48.3 \mathrm{~b}$ & $35.2 \mathrm{~b}$ \\
\hline Mazzard & 9.4 & 11.7 & 11.3 & 12.2 & $63.3 \mathrm{~b}$ & $60.8 \mathrm{~b}$ & $65.1 \mathrm{ab}$ & $44.1 \mathrm{ab}$ \\
\hline Significance & NS & NS & NS & NS & $* *$ & $* * * *$ & * & $*$ \\
\hline
\end{tabular}

${ }^{2}$ Mean separation in columns by Duncan's multiple range test at $P \leq 0.05$.

ns, ${ }^{*}, * *, * * *, * * * *$ Nonsignificant or significant at $P \leq 0.05,0.01,0.001$, or 0.0001 , respectively.

for rootstocks GM 61/1 and MxM2. Manganese deficiency has been frequently reported for cherry (Westwood and Wann, 1966), but leaf $\mathrm{Mn}$ concentrations were low $\left(<20 \mu \mathrm{g} \cdot \mathrm{g}^{-1}\right)$ only for rootstock GM 61/1 in 1991 (Table 4). For $\mathrm{Cu}$, rootstocks were identified that generally resulted in higher (MxM2) or lower (GM 61/1 and GI 195/1) leaf $\mathrm{Cu}$ concentrations than Mazzard (Table 2). However, leaf $\mathrm{Cu}$ concentrations for rootstocks throughout the study were consistently normal, ranging from

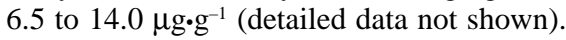
Considering the rarity of occurrence of $\mathrm{Cu}$ deficiency in cherry, such differences in $\mathrm{Cu}$ accumulation are unlikely to be of practical significance.

\section{Conclusions}

In the early years of this NC-140 cherry planting, several rootstocks, including GM 79, GI 148/1, GI 195/1, and GI 196/4, produced higher yields than Mazzard, the industry standard. Less promising have been results for tree size, with most rootstocks resulting in similar or larger (Colt) trees relative to
Mazzard. Only GM 61/1 and GM 9 have exhibited some degree of dwarfing. Rootstocks significantly affected leaf nutrient concentration during the 4 years of study. Importantly, the four rootstocks with higher yields than Mazzard generally had lower leaf K concentrations, paralleling similar decreases in leaf K concentration associated with crop load increases for apple. Also, all except GM 79 had lower Mg concentrations, while half (GI 195/ 1 and 196/4) contained less N than Mazzard. Increased attention to $\mathrm{K}, \mathrm{Mg}$, and $\mathrm{N}$ nutrition may be required should higher-yielding rootstocks be used, especially on soil with poor capability to supply these nutrients. In contrast, use of these high-yielding rootstocks would not likely alter strategies for micronutrient nutrition with, for example, none of these rootstocks capable of altering the low $\mathrm{Zn}$ status of cherries commonly observed in the Pacific Northwest. Trees on rootstock GM 9, more dwarfing than Mazzard, shared the generally lower leaf K concentration of the higheryielding rootstocks but often had higher leaf $\mathrm{P}$, $\mathrm{Mg}$, and Mn than Mazzard. Trees on rootstock GM 61/1, also dwarfing, had lower leaf con- 
centrations of most measured nutrients, relative to Mazzard, raising the possibility that inadequate nutrition was, in part, the cause of smaller tree size. Other specific rootstocks were identified that increased leaf concentration of individual nutrients relative to Mazzard, including Colt for $\mathrm{Mg}$ and $\mathrm{Ca}$ and $\mathrm{MxM} 2$ for $\mathrm{Cu}$. Other rootstocks were identified that usually had lower leaf concentrations, including Colt for K and MxM60 for Ca.

\section{Literature Cited}

Bould, C. 1966. Leaf analysis of deciduous fruits, p. 651-684. In: N.F. Childers (ed.). Nutrition of fruit crops. Hort. Publ., Rutgers N.J.

British Columbia Ministry of Agriculture, Fisheries and Food. 1995. Tree fruit production guide for interior districts for commercial growers, Victoria, B.C.

Brown, S.K. and J.N. Cummins. 1989. Rootstock effect on foliar nutrient concentrations of 'Redhaven' peach trees. HortScience 24:769-771.

Chaplin, M.H. and M.N. Westwood. 1980. Effects of Pyrus species and related genera rootstocks on mineral uptake in 'Bartlett' pear. J. Plant Nutr. 2:335-346.

Fallahi, E. and M.N. Westwood. 1984. Influence of apple rootstocks and $\mathrm{K}$ and $\mathrm{N}$ fertilizers on leaf mineral composition and yield in a high density orchard. J. Plant Nutr. 7:1161-1177.

Hanson, E.J. and R.L. Perry. 1989. Rootstocks influence mineral nutrition of 'Montmorency' sour cherry. HortScience. 24:916-918.

Hanson, E.J. and E.L. Proebsting. 1995. Cherry nutrient requirements and water relations, $\mathrm{p}$. 243-257. In: A.D. Webster and N.E. Looney (eds.). Cherries, crop physiology, production and uses. CAB Intl., Oxford, U.K.

Hanson, P. 1980. Crop load and nutrient translocation, p. 201-212. In: D. Atkinson et al. (eds.). Mineral nutrition of fruit trees. Butterworths, London.

Jadczuk, E. 1993. Some factors affecting potassium nutrition of sour cherry trees, p. 127-132. In: M.A.C. Fragoso and M.L. Beusichem (eds.). Optimization of plant nutrition. Kluwer Academic Publishers, Netherlands.

Lord, W.J., D.W. Greene, R.A. Damon, Jr., and J.H. Baker. 1985. Effects of stempiece and rootstock combinations on growth, leaf mineral concentrations, yield, and fruit quality of 'Empire' apple trees. J. Amer. Soc. Hort. Sci. 110: 422 425.

Neilsen, G.H. 1988. Seasonal variation in leaf zinc concentration of apples receiving dormant zinc. HortScience. 23:130-132.

Neilsen, G.H. and E.J. Hogue. 1992. Long-term effects of orchard soil management on tree vigor and extractable soil nutrients. Can. J. Soil Sci. 72:617-621.
Perry, R.L. 1987. Cherry rootstocks, p. 217-264. In: R.C. Rom and R.F. Carlson (eds.). Rootstocks for fruit crops. Wiley, New York.

SAS Institute. 1985. SAS user's guide: Statistics. 5th ed. SAS Inst., Cary, N.C.

Shear, C.B. and M. Faust. 1980. Nutritional ranges in deciduous tree fruits and nuts. Hort. Rev. 2:142-163.

Simons, R.K. and J.W. Swiader. 1985. The effects of apple dwarfing rootstocks on leaf nutrient element composition in stoolbed production. J. Plant Nutr. 8:933-943.

Ugolik, M. and T. Hulobowicz. 1990. The influence of rootstock and cultivar on the leaf content of nutrient elements, growth and yield of three sour cherry cultivars. Acta Hort. 274:491-499.

Webster, A.D. and H. Schmidt. 1995. Rootstocks for sweet and sour cherries, p. 127-163. In: A.D. Webster and N.E. Looney (eds.). Cherries, crop physiology, production and uses. CAB Intl., Oxford, U.K

Westwood, M.N. and F.B. Wann. 1966. Cherry nutrition, p. 158-173. In: N.F. Childers (ed.). Nutrition of fruit crops. Hort. Publ., Rutgers, N.J.

Wittneben, U. 1986. Soils of the Okanagan and Similkameen Valleys. Min. of Environment Technical Rpt. 18. Rpt. 52. British Columbia Soil Survey, Victoria, B.C.

Ystaas, J. 1990. The influence of cherry rootstocks on the content of major nutrients of 3 sweet cherry cultivars. Acta Hort. 274:517-519. 